\title{
KEEFEKTIFAN BEBERAPA DOSIS INSEKTISIDA NABATI BABADOTAN (Ageratum conyzoides L.) TERHADAP KUMBANG BUBUK BIJI JAGUNG (Sitophilus zeamais M.) DI PENYIMPANAN
}

\author{
The Effectiveness of Some Doses of Babadotan Botanical Insecticide \\ (Ageratum conyzoides L.) towards Corn Kernels Powder Beetle \\ (Sitophilus zeamais M.) Pest in Storage
}

\author{
Rahmida Sari ${ }^{1}$ dan Desita Salbiah ${ }^{2}$ \\ ${ }^{1)}$ Mahasiswa Jurusan Agroteknologi, Fakultas Pertanian, Universitas Riau \\ ${ }^{2)}$ Dosen jurusan Agroteknologi, Fakultas Pertanian, Universitas Riau \\ Email: Rahmidasari092@gmail.com/ 082385605474
}

[Diterima: Desember 2019; Disetujui: April 2020]

\begin{abstract}
Sitophilus zeamais M. is a storage pest that attacks corn kernels in the storage. Pest control strategies in storage which are often carried out are chemicals, namely insecticides in the form of fumigants. One of them is using plant-based insecticides. Babadotan is a plant that can be used as a botanical insecticide. This research aimed to obtain an effective dose of babadotan flour towards the mortality of $S$. zeamais pest. This research was conducted at the Plant Pest Laboratory, Faculty of Agriculture, Riau University from March to May 2019. The research was conducted experimentally using a completely randomized design (CRD) with 6 treatments and 4 replications. Treatment given was babadotan flour with the following dosage: Babadotan flour dose $0 \mathrm{~g} .100 \mathrm{~g}-1$ corn kernels, 2 g.100 g-1 corn kernels, 4 g. 100 g-1 corn kernels, 6 g. 100 g-1 corn kernels, 8 g. 100 g-1 corn kernels, and 10 g.100 g-1 corn kernels. Dose 10 g.100 g-1 babadotan flour corn kernels is an effective dose to control Sitophilus zeamais which can cause total mortality of $82.5 \%$ with an initial death of 79,75 hours after application and Lethal time 50254 hours after application. Application of babadotan flour with a dose of $10 \mathrm{~g} .100 \mathrm{~g}-1$ corn kernels produced the lowest percentage of corn seed shrinking at $9,55 \%$ and resulted in the least individual increase of 4,75 tails.
\end{abstract}

Keywords: Ageratum conyzoides L., Sitophilus zeamais M., Corn

\begin{abstract}
ABSTRAK
Sitophilus zeamais M. adalah hama gudang yang menyerang biji jagung di gudang. Strategi pengendalian hama di penyimpanan yang sering dilakukan adalah dengan bahan kimia yaitu insektisida berupa fumigan. Salah satunya dengan menggunakan insektisida nabati. Babadotan merupakan tumbuhan yang dapat dimanfaatkan sebagai insektisida nabati. Penelitian bertujuan untuk mendapatkan dosis tepung babadotan yang efektif terhadap mortalitas hama kumbang bubuk biji jagung S. zeamais. Penelitian ini dilakukan di Laboratorium Hama Tumbuhan, Fakultas Pertanian, Universitas Riau dari bulan Maret hingga Mei 2019. Perlakuan yang diberikan adalah pemberian tepung babadotan dengan dosis sebagai berikut: Dosis tepung babadotan 0 g. $100 \mathrm{~g}^{-1}$ jagung, $2 \mathrm{~g} .100 \mathrm{~g}^{-}$ ${ }^{1}$ jagung, 4 g. $100 \mathrm{~g}^{-1}$ jagung, 6 g. $100 \mathrm{~g}^{-1}$ jagung, 8 g.100 g ${ }^{-1}$ jagung, dan $10 \mathrm{~g} .100 \mathrm{~g}^{-1}$ jagung. Penelitian dilakukan secara eksperimen menggunakan rancangan acak lengkap (RAL) dengan 6 perlakuan dan 4 ulangan. Berdasarkan hasil penelitian, dosis tepung babadotan $10 \mathrm{~g} .100 \mathrm{~g}^{-1}$ jagung merupakan dosis yang efektif untuk mengendalikan Sitophilus zeamais dimana dapat menyebabkan mortalitas total sebesar 82,5\% dengan awal kematian 79,75 jam setelah aplikasi dan $\mathrm{LT}_{50} 254$ jam setelah aplikasi. Pemberian tepung babadotan dengan dosis $10 \mathrm{~g} .100 \mathrm{~g}^{-1}$ jagung menghasilkan persentase penyusutan biji jagung yang paling rendah yaitu $9,55 \%$ dan menghasilkan pertambahan individu paling sedikit yaitu 4,75 ekor.
\end{abstract}

Keywords: Ageratum conyzoides L., Sitophilus zeamais M., Biji Jagung. 


\section{PENDAHULUAN}

Kerusakan yang ditimbulkan S. zeamais dapat diatasi dengan melakukan pengendalian. Strategi pengendalian hama di penyimpanan yang sering dilakukan hingga saat ini adalah fumigasi dan penggunaan insektisida sintetik (Dadang et al. 2004 dalam Trishadewi, 2017). Fumigasi adalah salah satu cara pengendalian yang efektif untuk mengendalikan hama pada bahan simpanan. Senyawa kimia sintetik yang biasa digunakan sebagai fumigan adalah metil bromida dan karbon tetrachlorida (Kartasapoetra, 1987). Alternatif yang cukup tepat untuk mengatasi permasalahan tersebut yaitu dengan menggunakan insektisida nabati yang aman bagi lingkungan. Tumbuhan insektisida nabati yang aman bagi lingkungan adalah babadotan.

Hasil penelitian Gani (2010), pemberian tepung daun babadotan $100 \mathrm{~g} .1000 \mathrm{~g}^{-1}$ beras menyebabkan mortalitas imago kumbang beras (Sitophilus oryzae) sebesar 92,25\%. Dadang dan Prijono (2008) menyatakan bahwa pestisida nabati dikatakan efektif apabila perlakuan tersebut dapat mengakibatkan kematian serangga uji melebihi $80 \%$. Sejauh ini penelitian tepung babadotan secara fumigan belum banyak dilakukan untuk mengendalikan hama S. zeamais.

\section{METODE PENELITIAN}

Penelitian telah dilaksanakan di Laboratorium Hama Tumbuhan Fakultas Pertanian Universitas Riau, Kampus Bina

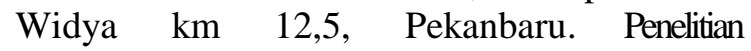
dilaksanakan selama tiga bulan dari bulan Maret sampai Mei 2019. Bahan yang digunakan dalam penelitian adalah imago $S$. zeamais, biji jagung varietas Sukma Raga dari Dinas Pertanian Rengat Barat Indragiri Hulu, dan tepung babadotan (Ageratum conyzoides L.) Alat yang digunakan dalam penelitian adalah stoples plastik ukuran panjang $17 \mathrm{~cm}$, tinggi $3,5 \mathrm{~cm}$, dan lebar $11,5 \mathrm{~cm}$, aspirator, kain tille 28 mesh, timbangan analitik, gunting, blender, termohygrometer, ayakan 40 mesh, kertas label, isolasi, kertas tissue kasar, kamera dan alat tulis.

Penelitian dilakukan secara eksperimen dengan menggunakan rancangan acak lengkap (RAL) yang terdiri dari 6 perlakuan, setiap perlakuannya diulang 4 kali sehingga diperoleh 24 unit percobaan. Penelitian terdiri dari 2 seri, seri pertama terdiri dari 24 unit percobaan yang digunakan untuk pengamatan waktu awal kematian S. zeamais, lethal time $50\left(\mathrm{LT}_{50}\right)$, mortalitas harian dan mortalitas total. Unit percobaan seri kedua digunakan untuk pengamatan penyusutan berat biji jagung dan pertambahan individu $S$. zeamais, sehingga didapatkan 48 unit percobaan. Setiap unit percobaan diinfestasikan sebanyak 10 ekor imago $S$. zeamais yang terdiri dari 5 ekor imago jantan dan 5 ekor imago betina, dengan jumlah biji jagung yang dimasukkan pada setiap perlakuan sebanyak $100 \mathrm{~g}$ disetiap stoples.

Perlakuan yang diberikan adalah pemberian tepung babadotan dengan dosis sebagai berikut: Dosis tepung babadotan 0 g.100 g ${ }^{-1}$ jagung, 2 g.100 g ${ }^{-1}$ jagung, 4 g. $100 \mathrm{~g}^{-}$ ${ }_{1}^{1}$ jagung, $6 \mathrm{~g} .100 \mathrm{~g}^{-1}$ jagung, $8 \mathrm{~g} .100 \mathrm{~g}^{1}$ jagung, dan 10 g. $100 \mathrm{~g}^{-1}$ jagung Pelaksanaan penelitian meliputi: persiapan biji jagung, pengukuran kadar air, perbanyakan S. zeamais, aplikasi tepung babadotan. Parameter yang diamati adalah waktu awal kematian, lethal time 50, mortalitas harian, mortalitas total, pertambahan individu $S$. zeamais, dan penyusutan berat biji jagung. Data yang diperoleh dari hasil penelitian dianalisis secara statistik dan diuji lanjut dengan dengan menggunakan uji Beda Nyata Jujur (BNJ) pada taraf 5\%.

\section{HASIL DAN PEMBAHASAN}

\section{Waktu Awal Kematian}

Hasil sidik ragam menunjukkan bahwa perlakuan beberapa dosis tepung babadotan (Ageratum conyzoides L.) memberikan perbedaan yang nyata terhadap waktu awal kematian $S$. zeamais hasil rata-rata waktu awal kematian $S$. zeamais setelah dilakukan uji BNJ pada taraf 5\% dapat dilihat pada Tabel 1 . 
Tabel 1. Rata-rata waktu awal kematian $S$. zeamais setelah pemberian beberapa dosis tepung babadotan (Ageratum conyzoides L.)

\begin{tabular}{cc}
\hline Dosis tepung babadotan & Waktu awal kematian (jam) \\
\hline $0 \mathrm{~g} \cdot 100 \mathrm{~g}^{-1}$ & $504,0 \mathrm{a}$ \\
$2 \mathrm{~g} \cdot 100 \mathrm{~g}^{-1}$ & $188,5 \mathrm{~b}$ \\
$4 \mathrm{~g} \cdot 100 \mathrm{~g}^{-1}$ & $184,7 \mathrm{~b}$ \\
$6 \mathrm{~g} \cdot 100 \mathrm{~g}^{-1}$ & $151,5 \mathrm{c}$ \\
$8 \mathrm{~g} \cdot 100 \mathrm{~g}^{-1}$ & $93,5 \mathrm{~d}$ \\
$10 \mathrm{~g} \cdot 100 \mathrm{~g}^{-1}$ & $79,7 \mathrm{e}$ \\
\hline
\end{tabular}

Angka-angka pada lajur yang diikuti oleh huruf kecil yang tidak sama berbeda nyata menurut uji BNJ pada taraf 5\%

Hasil pengamatan menunjukkan dari empat dosis tepung babadotan yaitu

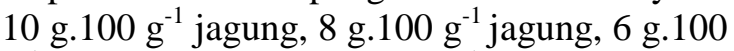
$\mathrm{g}^{-1}$ jagung dan 0 g.100 $\mathrm{g}^{-1}$ jagung saling berbeda nyata masing-masing menyebabkan waktu awal kematian selama 79,7 jam, 93,5 jam, 151,5 jam dan 504,0 jam setelah aplikasi, namun dosis tepung babadotan 4 g.100 g $\mathrm{g}^{-1}$ jagung berbeda tidak nyata dengan dosis tepung babadotan 2 g. $100 \mathrm{~g}^{-1}$ jagung masingmasing menyebabkan waktu awal kematian 184,7 jam dan 188,5 jam setelah aplikasi. Hal ini diduga semakin rendah dosis tepung babadotan yang digunakan menyebabkan kandungan bahan aktif kumarin jenis surangin B di dalam tepung babadotan semakin rendah dan mempengaruhi waktu awal kematian. Pendapat ini sesuai dengan pernyataan Aminah (1995) bahwa rendahnya dosis akan mempengaruhi kandungan bahan aktif dan akan berpengaruh terhadap waktu kematian serangga uji. Perubahan tingkah laku $S$. zeamais dapat dilihat dari awal imago aktif bergerak dan makan, kemudian setelah beberapa hari aplikasi aktifitas imago menampakkan penurunan dengan ciri-ciri imago mulai bergerak lambat, kemudian imago banyak yang menempel di bagian atas atau tutup stoples. Perbedaan imago $S$. zeamais yang masih hidup dan mati akibat pemberian tepung babadotan dapat dilihat pada Gambar 1 .
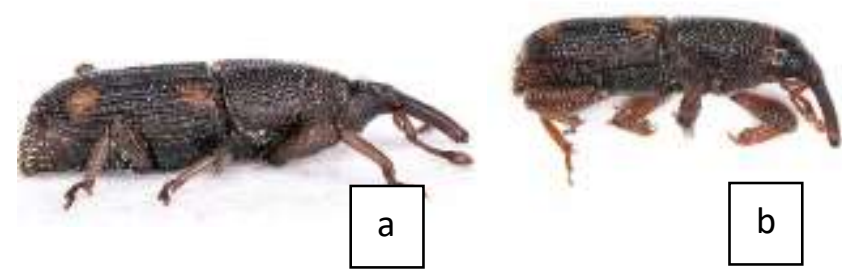

Gambar 1. Imago S. zeamais (a) hidup dan (b) mati (Dokumentasi penelitian, 2019)

\subsection{Lethal Time $50\left(\mathrm{LT}_{50}\right)$ (jam)}

Hasil sidik ragam menunjukkan bahwa perlakuan beberapa dosis tepung babadotan memberikan perbedaan yang nyata terhadap lethal time $50 \mathrm{~S}$. zeamais. Hasil rata-rata $\mathrm{LT}_{50}$ S. zeamais setelah dilakukan uji BNJ pada taraf $5 \%$ dapat dilihat pada Tabel 2.

Tabel 2. Rata-rata $\mathrm{LT}_{50}$ S. zeamais setelah pemberian beberapa dosis babadotan (A. conyzoides)

Dosis tepung babadotan

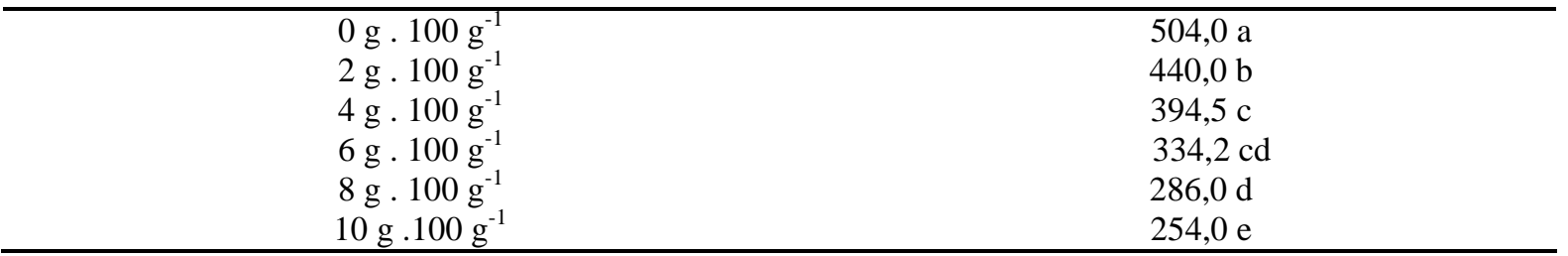

Lethal time 50 (jam)

Angka-angka pada lajur yang diikuti oleh huruf kecil yang tidak sama berbeda nyata menurut uji BNJ pada taraf $5 \%$.

Tabel 2 menunjukkan bahwa dosis tepung babadotan $10 \quad$ g.100 $\mathrm{g}^{-1}$ jagung cenderung lebih cepat dalam mematikan $50 \%$ S. zeamais yaitu 254 jam setelah aplikasi.
Dosis tepung babadotan $10 \mathrm{~g} .100 \mathrm{~g}^{-1}$ jagung berbeda nyata dengan dosis lainnya. Hal ini berkaitan dengan awal kematian bahwa 
dosis tepung babadotan $10 \mathrm{~g} .100 \mathrm{~g}^{-1}$ jagung menunjukkan awal kematian $S$. zeamais paling cepat sehingga mengakibatkan $\mathrm{LT}_{50}$ juga semakin cepat. Diduga dosis yang tinggi maka senyawa aktif kumarin surangin B menjadi tinggi sehingga semakin cepat waktu yang dibutuhkan untuk mematikan $S$. zeamais. Sesuai dengan pendapat Natawigena (1993) menyatakan bahwa proses kematian hama akan semakin cepat dengan pertambahan dosis yang digunakan.

Dosis tepung babadotan 8 g.100 $\mathrm{g}^{-1}$ jagung menyebabkan $\mathrm{LT}_{50}$ yaitu 286 jam setelah aplikasi berbeda tidak nyata dengan dosis 6 g.100 $\mathrm{g}^{-1}$ jagung menyebabkan $\mathrm{LT}_{50}$ yaitu 334,25 jam setelah aplikasi. Hal ini diduga karena dosis 6 g.100 g $\mathrm{g}^{-1}$ jagung telah mengandung senyawa aktif kumarin surangin B yang cukup banyak, sehingga tidak berbeda nyata dengan perlakuan dosis 8 g.100 $\mathrm{g}^{-1}$ jagung. Hal ini diperkuat dengan penelitian Andrianto et al. (2016) yang menunjukan waktu $\mathrm{LT}_{50}$ yang berbeda tidak nyata pada perlakuan tepung buah sirih hutan dengan dosis6 g. $100 \mathrm{~g}^{-1}$ beras dan 8 g. $100 \mathrm{~g}^{-1}$ beras untuk mematikan Sitophilus oryzae.

Dosis tepung babadotan 6 g.100 $\mathrm{g}^{-1}$ jagung berbeda tidak nyata dalam mematikan $50 \%$ S. zeamais dengan dosis 4 g. $100 \mathrm{~g}^{-1}$ menyebabkan $\mathrm{LT}_{50}$ selama 394,5 jam setelah

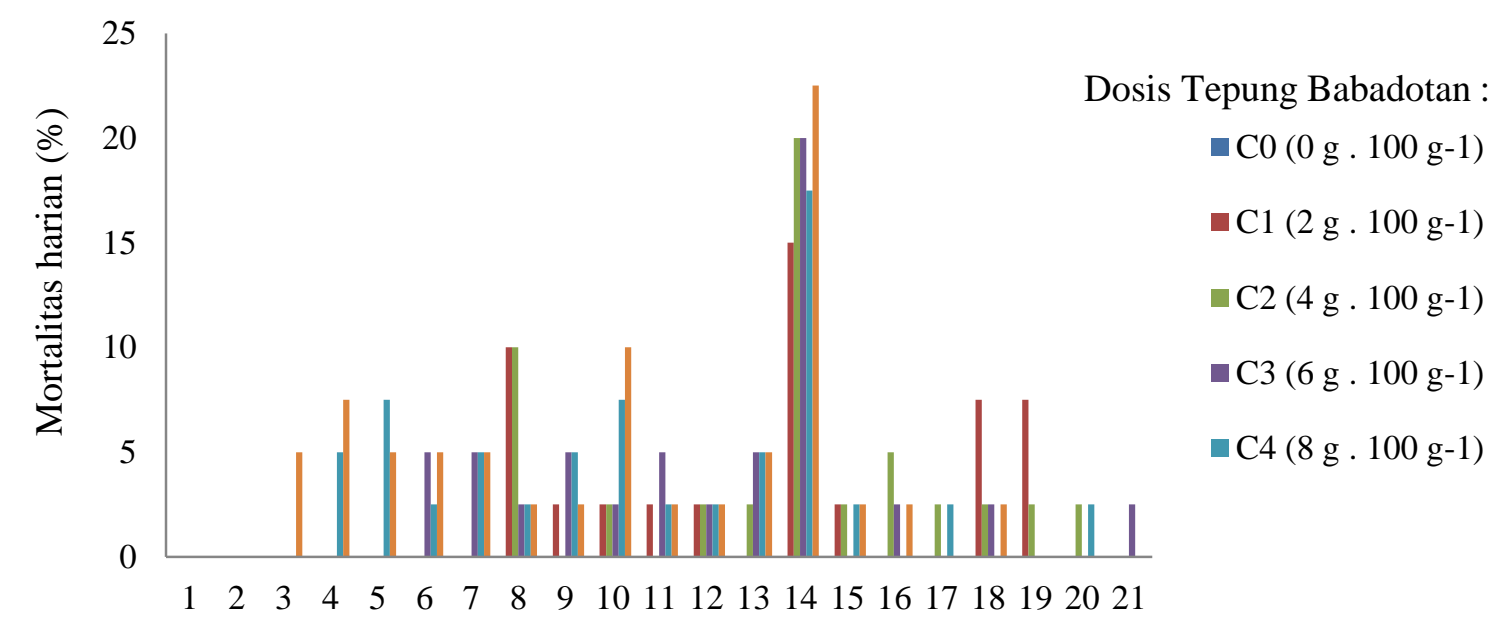

Hari Setelah Aplikasi (HSA) aplikasi, namun dosis tepung babadotan 4 g. $100 \mathrm{~g}^{-1}$ jagung berbeda nyata dengan dosis 2 g.100 $\mathrm{g}^{-1}$ jagung menyebabkan $\mathrm{LT}_{50}$ selama 440 jam setelah aplikasi. Hal ini berbeda dengan waktu awal kematian dimana dosis 4 g.100 $\mathrm{g}^{-1}$ jagung dan 2 g.100 $\mathrm{g}^{-1}$ jagung menunjukkan hasil yang berbeda tidak nyata. Diduga dosis yang rendah menyebabkan senyawa kumarin surangin B bekerja secara lambat sehingga pada waktu awal kematian bahan aktif kumarin surangin B belum bekerja secara maksimal untuk mematikan $S$. zeamais dan diduga karena insektisida nabati bekerja dengan lambat sehingga membutuhkan waktu yang lama untuk mematikan $S$. zeamais. Hal ini sesuai dengan pernyataan Yunianti (2016) dalam Trishadewi (2017) bahwa mortalitas akan terjadi lebih lambat pada dosis yang rendah dikarenakan semakin sedikit bahan aktif yang masuk ke dalam tubuh serangga.

\subsection{Mortalitas Harian Sitophilus zeamais (\%) \\ Hasil pengamatan mortalitas harian} hama $S$. zeamais dengan perlakuan beberapa dosis tepung babadotan menunjukkan bahwa persentase kematian $S$. zeamais mengalami fluktuasi dari hari pertama hingga hari ke 21 . Fluktuasi mortalitas harian $S$. zeamais dapat dilihat pada Gambar 2.

Gambar 2. Fluktuasi mortalitas harian S. zeamais pemberian tepung babadotan

Gambar 2 menunjukkan puncak mortalitas harian tertinggi terjadi pada dosis tepung babadotan $10 \mathrm{~g} .100 \mathrm{~g}^{-1}$ jagung sebesar $22,5 \%$. Hal ini diduga karena bahan aktif kumarin surangin B masuk melalui sistem pernafasan mematikan $S$. zeamais secara lambat sehingga pada hari ke 14 baru mengalami kematian yang tinggi. Pendapat ini sesuai dengan pernyataan Hartati (2012) yang menyatakan bahwa insektisida nabati yang diaplikasikan secara fumigan tidak mematikan serangga secara cepat. 
Dosis tepung babadotan $10 \mathrm{~g} .100 \mathrm{~g}^{-1}$ jagung mortalitas harian mulai terjadi pada hari ke 3 sebesar $5 \%$ selanjutnya mengalami fluktuasi hingga hari ke 10 yang meningkat sebesar $10 \%$. Hal ini diduga karena insektisida nabati bahan aktif kumarin surangin $\mathrm{B}$ bekerja dengan lambat sehingga pada hari ke 3 baru terjadi kematian. Pendapat ini sesuai dengan hasil penelitian Sembiring (2013) bahwa insektisida nabati bekerja secara lambat sehingga mortalitas harian mulai terjadi pada hari ke 3 setelah aplikasi sebesar 5\% pada dosis $10 \mathrm{~g} .100 \mathrm{~g}^{-1}$ jagung.

Pemberian dosis tepung babadotan 4 g.100 g $\mathrm{g}^{-1}$ dan 2 g.100 $\mathrm{g}^{-1}$ jagung mortalitas harian mulai terjadi pada hari ke 8 sebesar $10 \%$ dan mengalami fluktuasi hingga akhir penelitian. Pada hari ke 18 dan 19 dosis tepung babadotan 2 g.100 $\mathrm{g}^{-1}$ jagung meningkat kembali yang mampu mematikan $S$. zeamais sebesar 7,5\%. Hal ini diduga karena dosis yang diberikan rendah menyebabkan bahan aktif kumarin surangin $\mathrm{B}$ rendah sehingga membutuhkan waktu lebih lama dalam mematikan $S$. zeamais dan diduga $S$. zeamais yang masih bertahan mulai melemah akibat pemberian dosis tepung babadotan. Hal ini sesuai dengan penelitian Sembiring (2013) bahwa pada hari ke 21 terjadi peningkatan kembali pada dosis 2 g.100 g ${ }^{-1}$ jagung dan 4 g.100 $\mathrm{g}^{-1}$ jagung mampu mematikan hama sebesar $7,5 \%$ dan $10 \%$.

\subsection{Mortalitas Total Sitophilus zeamais(\%)}

Hasil sidik ragam menunjukkan bahwa perlakuan beberapa dosis tepung babadotan memberikan perbedaan yang nyata terhadap mortalitas total $S$. zeamais. Hasil rata-rata mortalitas total $S$. zeamais setelah dilakukan uji BNJ pada taraf 5\% dapat dilihat pada Tabel 3.

Tabel 3. Rata-rata mortalitas total S. zeamais setelah pemberian beberapa dosis tepung babadotan (A. conyzides)

\begin{tabular}{cc}
\hline Dosis tepung babadotan & Mortalitas total (\%) \\
\hline $0 \mathrm{~g} \cdot 100 \mathrm{~g}^{-1}$ & $00,0 \mathrm{a}$ \\
$2 \mathrm{~g} \cdot 100 \mathrm{~g}^{-1}$ & $52,5 \mathrm{~b}$ \\
$4 \mathrm{~g} \cdot 100 \mathrm{~g}^{-1}$ & $55,0 \mathrm{~b}$ \\
$6 \mathrm{~g} \cdot 100 \mathrm{~g}^{-1}$ & $60,0 \mathrm{bc}$ \\
$8 \mathrm{~g} \cdot 100 \mathrm{~g}^{-1}$ & $70,0 \mathrm{c}$ \\
$10 \mathrm{~g} \cdot 100 \mathrm{~g}^{-1}$ & $82,5 \mathrm{~d}$ \\
\hline
\end{tabular}

Angka-angka pada lajur yang diikuti oleh huruf kecil yang tidak sama berbeda nyata menurut uji BNJ pada taraf $5 \%$ setelah ditransformasikan dengan rumus arcsin atau $\sin ^{-1} \sqrt{y}+0,5$

Tabel 3 menunjukkan bahwa semakin tinggi dosis tepung babadotan yang diberikan, maka mortalitas total $S$. zeamais semakin tinggi. Dosis tepung babadotan $10 \mathrm{~g} .100 \mathrm{~g}^{-1}$ jagung mampu mematikan $S$. zeamais sebesar $82,5 \%$ di akhir pengamatan dan dapat dikatakan efektif jika digunakan sebagai pestisida nabati. Pendapat ini sesuai dengan pernyataan Dadang dan Prijono (2008) yang mengemukakan bahwa pestisida nabati dikatakan efektif apabila perlakuan tersebut dapat mengakibatkan kematian serangga uji melebihi $80 \%$.

Mortalitas total $S$. zeamais dosis tepung babadotan $10 \mathrm{~g} .100 \mathrm{~g}^{-1}$ jagung berbeda nyata dengan semua dosis. Dosis tepung babadotan 8 g.100 $\mathrm{g}^{-1}$ jagung menunjukkan persentase mortalitas total S. zeamais sebesar $70 \%$, berbeda tidak nyata dengan dosis 6 g. $100 \mathrm{~g}^{-1}$ jagung mortalitas total sebesar $60 \%$. Dosis tepung babadotan 6 g. $100 \mathrm{~g}^{-1}$ jagung berbeda tidak nyata dengan dosis tepung babadotan 4 g.100 $\mathrm{g}^{-1}$ jagung dan 2 g.100 $\mathrm{g}^{-1}$ jagung menunjukkan persentase mortalitas total $S$. zeamais sebesar $55 \%$ dan $52,5 \%$.

4.6 Pertambahan Individu $S$. zeamais (ekor)

Hasil sidik ragam menunjukkan bahwa perlakuan beberapa dosis tepung babadotan memberikan perbedaan yang nyata terhadap pertambahan individu $S$. zeamais. Hasil ratarata pertambahan individu setelah dilakukan uji BNJ pada taraf $5 \%$ dapat dilihat pada Tabel 4.

Tabel 4 menunjukkan bahwa perlakuan tepung babadotan dengan dosis yang berbeda memberikan perbedaan yang nyata terhadap jumlah keturunan $S$. zeamais. Dosis tepung babadotan $10 \mathrm{~g} .100 \mathrm{~g}^{-1}$ jagung yang merupakan pertambahan individu terendah yaitu 4,75 ekor dan berbeda nyata dengan dosis lainnya. Dosis tepung babadotan $8 \quad$ g.100 $\mathrm{g}^{-1}$ jagung pertambahan individu yaitu 11,5 ekor berbeda tidak nyata dengan dosis $6 \mathrm{~g} .100 \mathrm{~g} \mathrm{~g}^{-1}$ jagung dan 4 g.100 $\mathrm{g}^{-1}$ jagung pertambahan individu 
sebanyak 16,25 ekor. Hal ini berkaitan dengan mortalitas total $S$. zeamais dimana, semakin tinggi dosis yang diberikan maka semakin tinggi mortalitas total sehingga jumlah individu yang hidup semakin sedikit menyebabkan telur yang diletakkan juga sedikit. Jumlah individu yang hidup sedikit menyebabkan telur yang diletakkan juga sedikit sehingga pertambahan individu juga sedikit. Sesuai dengan pendapat Hasna dan Usamah (2010) menyatakan bahwa rendahnya jumlah imago $S$. zeamais akan menyebabkan kemampuan meletakkan telur dan jumlah telur yang menetas menjadi individu baru akan sedikit.

Tabel 4. Rata-rata pertambahan individu S. zeamais setelah pemberian beberapa dosis tepung babadotan (A. conyzoides)

\begin{tabular}{cc}
\hline Dosis tepung babadotan & Pertambahan individu (ekor) \\
\hline $0 \mathrm{~g} \cdot 100 \mathrm{~g}^{-1}$ & $21,2 \mathrm{a}$ \\
$2 \mathrm{~g} .100 \mathrm{~g}^{-1}$ & $20,7 \mathrm{a}$ \\
$4 \mathrm{~g} \cdot 100 \mathrm{~g}^{-1}$ & $16,2 \mathrm{ab}$ \\
$6 \mathrm{~g} \cdot 100 \mathrm{~g}^{-1}$ & $16,2 \mathrm{ab}$ \\
$8 \mathrm{~g} \cdot 100 \mathrm{~g}^{-1}$ & $11,5 \mathrm{~b}$ \\
$10 \mathrm{~g} .100 \mathrm{~g}^{-1}$ & $4,7 \mathrm{c}$ \\
\hline
\end{tabular}

Angka-angka pada lajur yang diikuti oleh huruf kecil yang tidak sama berbeda nyata menurut uji BNJ pada taraf 5\%

Dosis tepung babadotan 0 g.100 $\mathrm{g}^{-1}$ jagung menghasilkan pertambahan individu yang cenderung lebih tinggi yaitu 21,25 ekor dan berbeda tidak nyata dengan dosis 2 g. 100 $\mathrm{g}^{-1}$ jagung. Hal ini karena dosis $0 \mathrm{~g} .100 \mathrm{~g}^{-1}$ jagung tidak diberikan perlakuan tepung babadotan sehingga tidak ada senyawa kumarin surangin B yang menyebabkan kematian S. zeamais hingga akhir pengamatan dan $S$. zeamais tetap melakukan proses perkembangbiakan dengan baik untuk menghasilkan individu baru. Pertambahan individu S. zeamais dapat dipengaruhi oleh beberapa faktor. Menurut Kartasapoetra (1987) bahwa faktor yang mempengaruhi pertambahan individu $S$. zeamais diantaranya kadar air bahan, tempat penyimpanan, suhu dan kelembaban. Kondisi yang sesuai untuk pertumbuhan $S$. zeamais adalah dengan suhu $17-34^{\circ} \mathrm{C}$ dengan suhu optimal $28^{\circ} \mathrm{C}$, kelembaban relatif antara $45-100 \%$ dan kelembaban optimal $70 \%$.

Hasil penelitian menunjukkan rata-rata suhu selama penyimpanan satu bulan yaitu $27,50^{\circ} \mathrm{C}$ dan rata-rata kelembaban selama satu bulan yaitu $80,23 \%$. Faktor seperti suhu dan kelembaban di Laboratorium mampu mendukung pertambahan individu $S$. zeamais, sehinga pada dosis yang tinggi juga terjadi pertambahan individu $S$. zeamais karena kondisi yang sesuai untuk $S$. zeamais dapat hidup dengan suhu $17-34^{\circ} \mathrm{C}$ dan kelembaban relatif $45-100 \%$. Hal ini sesuai dengan pendapat Kartasapoetra (1987) kondisi yang sesuai untuk pertumbuhan S. zeamais adalah dengan suhu $17-34{ }^{\circ} \mathrm{C}$ dengan suhu optimal $28^{\circ} \mathrm{C}$, kelembaban relatif antara $45-100 \%$ dan kelembaban optimal $70 \%$.

Faktor lainnya seperti kadar air mampu mendukung pertambahan individu $S$. zeamais karena kadar air biji jagung yang terdapat pada penelitian sebesar 13,36\% melebihi kadar air yang aman dalam penyimpanan yaitu kurang dari $12 \%$ sehingga pada dosis yang tinggi $S$. zeamais masih bisa bertahan hidup dan berkembangbiak. Hal ini sesuai dengan pendapat Bergvinson (2002) bahwa perkembangan populasi $S$. zeamais akan meningkat pada kadar air $15 \%$ atau lebih dan kadar air yang aman dalam penyimpanan yaitu kurang dari $12 \%$. Demikian pula pendapat Syarief dan Halid (1993) kadar air yang aman dari gangguan kerusakan adalah 11-12\%.

\subsection{Penyusutan Berat Biji Jagung (\%)}

Hasil sidik ragam menunjukkan bahwa perlakuan beberapa dosis tepung babadotan memberikan perbedaan yang nyata terhadap penyusutan berat biji jagung. Hasil rata-rata penyusutan berat biji jagung setelah dilakukan uji BNJ pada taraf 5\% dapat dilihat pada Tabel 5.

Tabel 5 menunjukkan bahwa semakin tinggi dosis yang diberikan menyebabkan persentase penyusutan berat biji jagung semakin rendah. Dosis tepung babadotan 10 g.100 $\mathrm{g}^{-1}$ jagung menyebabkan penyusutan berat biji jagung yang cenderung lebih rendah yaitu $9,55 \%$ dibandingkan dengan dosis lainnya. Dosis tepung babadotan 10 g. $100 \mathrm{~g}^{-1}$ jagung berbeda nyata dengan semua dosis. Dosis tepung babadotan 8 g.100 $\mathrm{g}^{-1}$ jagung 
menyebabkan penyusutan berat biji jagung sebesar $11,85 \%$ berbeda tidak nyata dengan dosis $6 \quad$ g.100 $\mathrm{g}^{-1}$ jagung menyebabkan penyusutan berat biji $14,77 \%$. Dosis tepung babadotan $6 \mathrm{~g} .100 \mathrm{~g}^{-1}$ jagung berbeda tidak nyata dengan dosis 4 g. $100 \mathrm{~g}^{-1}$ dan 2 g. $100 \mathrm{~g}^{-1}$ jagung. Dosis tepung babadotan $0 \mathrm{~g} .100 \mathrm{~g}^{-1}$ jagung menyebabkan penyusutan berat biji jagung sebesar $20,35 \%$ berbeda nyata dengan dosis lainnya.

Tabel 5. Rata-rata penyusutan berat biji jagung setelah pemberian beberapa dosis tepung babadotan (A. conyzoides)

\begin{tabular}{cc}
\hline Dosis tepung babadotan & Penyusutan berat biji jagung (\%) \\
\hline $0 \mathrm{~g} \cdot 100 \mathrm{~g}^{-1}$ & $20,3 \mathrm{a}$ \\
$2 \mathrm{~g} \cdot 100 \mathrm{~g}^{-1}$ & $17,0 \mathrm{ab}$ \\
$4 \mathrm{~g} \cdot 100 \mathrm{~g}^{-1}$ & $15,1 \mathrm{ab}$ \\
$6 \mathrm{~g} \cdot 100 \mathrm{~g}^{-1}$ & $14,7 \mathrm{bc}$ \\
$8 \mathrm{~g} \cdot 100 \mathrm{~g}^{-1}$ & $11,8 \mathrm{c}$ \\
$10 \mathrm{~g} \cdot 100 \mathrm{~g}^{-1}$ & $9,5 \mathrm{~d}$ \\
\hline
\end{tabular}

Angka-angka pada lajur yang diikuti oleh huruf kecil yang tidak sama berbeda nyata menurut uji BNJ pada taraf 5\% setelah ditransformasikan ke dalam $\sqrt{y}$

Hal ini berkaitan dengan mortalitas total $S$. zeamais dan pertambahan individu $S$. zeamais yang dihasilkan, semakin tinggi dosis yang diberikan maka semakin tinggi mortalitas total $S$. zeamais sehingga semakin sedikit pertambahan individu yang dihasilkan menyebabkan aktivitas makan akan semakin berkurang, sehingga akan mengurangi tingkat kerusakan dan penyusutan berat biji jagung. Pendapat ini sesuai dengan Pabbage et al. (1998) menyatakan bahwa besarnya kerusakan dan susut bobot bahan dalam simpanan tergantung dari tinggi rendahnya kepadatan populasi serangga yang ada.

\section{KESIMPULAN DAN SARAN}

\section{Kesimpulan}

1. Pemberian tepung babadotan dengan dosis 10 g.100 g ${ }^{-1}$ jagung merupakan dosis yang efektif untuk mengendalikan Sitophilus zeamais dimana dapat menyebabkan mortalitas total sebesar $82,5 \%$ dengan awal kematian 79,75 jam setelah aplikasi dan $\mathrm{LT}_{50} 254$ jam setelah aplikasi.

2. Pemberian tepung babadotan dengan dosis 10 g.100 $\mathrm{g}^{-1}$ jagung menghasilkan persentase penyusutan biji jagung yang paling rendah yaitu $9,55 \%$ dan menghasilkan pertambahan individu yang paling sedikit yaitu 4,75 ekor.

\section{Saran}

Pengendalian hama Sitophilus zeamais M. pada biji jagung disarankan menggunakan dosis tepung babadotan $10 \mathrm{~g} .100 \mathrm{~g}^{-1}$ jagung karena efektif mematikan hama Sitophilus zeamais M. sebesar $82,5 \%$.

\section{UCAPAN TERIMA KASIH}

Kepada Laboratorium Hama Tumbuhan Fakultas Pertanian Universitas Riau, Kampus

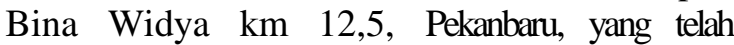
membantu kelancaran pelaksanaan penelitian ini.

\section{DAFTAR PUSTAKA}

Aminah, S. N. 1995. Evaluasi Tiga Jenis Tumbuhan Sebagai Insektisida dan Repelen terhadap Nyamuk di Laboratorium. Tesis (Tidak dipublikasikan). Institut Pertanian Bogor. Bogor.

Andrianto, B. S., R. Rustam dan A. Sutikno. 2016. Uji dosis tepung buah sirih hutan (Piper aduncum L.) terhadap mortalitas hama Sitophilus oryzae L. pada beras di penyimpinan. Jurnal Mahasiswa Faperta Universitas Riau. 3(1).

Dadang dan D. Prijono. 2008. Insektisida Nabati. Departemen Proteksi Tanaman. Institut Pertanian Bogor. Bogor.

Darmayanti, E. 2006. Pengaruh Ekstrak Daun Babadotan (Ageratum conyzoides L.) sebagai Insektisida Botani terhadap Mortalitas dan Perkembangan Ulat Kubis (Plutella xylostella L.). Skripsi (Tidak dipublikasikan) Universitas Jember. Jember.

Damayanti R., R. T. Himawan dan L.P. Astuti. 2013. Penghambatan reproduksi Rhyzopertha dominica F. (Coleoptera: Bostrichidae) menggunakan fumigan tablet berbasis minyak mimba. Jurnal HPT. 1(3).

Gani, S. 2010. Uji efektivitas tepung daun babadotan (Ageratum conyzoides L.) (Coleoptera: Curculionidae) di 
laboratorium. Jurnal Manggoro. 11 (1): 33-35.

Hartati, S. Y. 2012. Prospek pengembangan minyak atsiri sebagai pestisida nabati. Jurnal Pespektif. 11(1): 45-58.

Hasnah dan H. Usamah. 2010. Ektivitas ekstrak bawang putih terhadap mortalitas Sitophilus zeamais M. pada jagung di penyimpanan. Jurnal Floratek Universitas Syiah Kuala Banda Aceh. 5 (2): 1-10.

Kalshoven, L.G.E. 1981. Pests of Crops in Indonesia. PT. Ichtiar Baru-Van Hoeve. Jakarta.

Kardinan, A. 2004. Pestisida Nabati: Ramuan dan Aplikasi. Penebar Swadaya. Cetakan Kedua. Jakarta.

Kartasapoetra, A.G. 1987. Hama Hasil Tanaman dalam Gudang. Bina Aksara. Jakarta.

Mosip, E. B.T. Raharjo, L.P. Astuti. 2018. Toxicity test on wedusan (Ageratum spp.) extract against Sitophilus spp. (Coleoptera: Curculionidae). Journal of Tropical Life Science. 8(1): 11-15.

Mundolelono, B. 2005. Laju Perkembangan Hama Gudang Jagung Sitophilus zeamais. Balai Pengkajian Teknologi Pertanian Nusa Tenggara Timur. Nusa Tenggara Timur.

Natawigena, H. 1993. Dasar-Dasar Perlindungan Tanaman. Trigenda Karya. Bandung.

Nicholson, R.A dan Zhang A.G. 1995. Surangin B: Insecticidal properties and mechanism underlying its transmitter releasing action in nerve terminal fractions isolated from mammalian brain. Journal Pesticide Biochemistry and Physiology. 53(3): $152-163$.

Nonci, N. dan A. Muis, 2015. Biologi, gejala serangan, dan pengendalian hama bubuk jagung Sitophilus zeamais Motschulsky (Coleoptera: Cuculionidae). Jurnal Litbang Pertanian. 35(2): 61-70.

Pabbage, M. S., Masmawati dan S. Mas'ud. 1998. Callosobruchus chinensis dan strategi pengendaliannya. Jurnal Penelitian dan Informasi Pertanian. 8(2): 91-99.

Rizal, S. 2006. Pengaruh kadar air jagung yang disimpan terhadap pertumbuhan populasi kumbang jagung (Sitophilus zeamais M.). Jurnal Ripteksi PGRI. 2(1) : 81-94.
Saenong, M.S. 2013. Pemanfaatan Pestisida Nabati untuk Pertanian dan Kesehatan.www.Peipfi-

komdasulsel.org/wpcontent/uploads/2013/01/9pemanfaatan-pestisida-nabati.pdf. Diakses tanggal 1 April 2019

Sembiring, R. 2013. Pemberian Tepung Daun Sirsak (Annona muricata L.) dalam Mengendalikan Hama Kumbang Bubuk Jagung (Sitophilus zeamais M.) pada Biji Jagung di Penyimpanan. Skripsi (Tidak dipublikasikan). Universitas Riau. Pekanbaru.

Syarief, R dan H. Halid. 1993. Teknologi Penyimpanan Pangan. Arcan. Jakarta.

Trishadewi, P. 2017. Uji Beberapa Dosis Buah Sirih Hutan (Piper aduncun L.) untuk Mengendalikan Hama Callosobruchus chinensis L. pada Biji Kacang Hijau Dipenyimpanan. Skripsi (Tidak dipublikasikan) Universitas Riau. Pekanbaru.

Untung, K. 1993. Konsep Pengendalian Hama Terpadu. Andi offset. Yogyakarta.

Usman, L.A. M.F. Zubair, dan N.O.Olawore. 2013. Chemical constituents of flower essential oil of Ageratum conyzoides growing in Nigeria. Journal Organic Chemistry. 54 (13): 12463 - 12465.

Wagiman, F. X. 2014. Hama Pascapanen dan Pengolahannya. Gadjah Mada Univesity Press.Yogyakarta. 